\title{
Examining Changes in Stem Taper and Volume Growth with Two-Date 3D Point Clouds
}

\author{
Ville Luoma ${ }^{1,2, * \mathbb{D}}$, Ninni Saarinen ${ }^{1,2,3} \mathbb{D}$, Ville Kankare ${ }^{1,2,3}$, Topi Tanhuanpää 1,2,4, \\ Harri Kaartinen ${ }^{5,6} \mathbb{D}^{D}$, Antero Kukko ${ }^{2,5} \mathbb{D}$, Markus Holopainen ${ }^{1,2}$, Juha Hyyppä 2,5 \\ and Mikko Vastaranta ${ }^{2,3}$ (D) \\ 1 Department of Forest Sciences, University of Helsinki, FI-00014 Helsinki, Finland; \\ ninni.saarinen@helsinki.fi (N.S.); ville.kankare@uef.fi (V.K.); topi.tanhuanpaa@helsinki.fi (T.T.); \\ markus.holopainen@helsinki.fi (M.H.) \\ 2 Centre of Excellence in Laser Scanning Research, Finnish Geospatial Research Institute, P.O. Box-15, FI-02431 \\ Masala, Finland; antero.kukko@nls.fi (A.K.); juha.hyyppa@nls.fi (J.H.); mikko.vastaranta@uef.fi (M.V.) \\ 3 School of Forest Sciences, University of Eastern Finland, P.O. Box-111, FI-80101 Joensuu, Finland \\ 4 Department of Geographical and Historical Studies, University of Eastern Finland, P.O. Box-111, \\ FI-80101 Joensuu, Finland \\ 5 Department of Remote Sensing and Photogrammetry, Finnish Geospatial Research Institute, P.O. Box-15, \\ FI-02431 Masala, Finland; harri.kaartinen@nls.fi \\ 6 Department of Geography and Geology, University of Turku, FI-20014 Turun Yliopisto, Finland \\ * Correspondence: ville.luoma@helsinki.fi; Tel.: +358-44-047-6070
}

Received: 20 February 2019; Accepted: 26 April 2019; Published: 30 April 2019

\begin{abstract}
Exact knowledge over tree growth is valuable information for decision makers when considering the purposes of sustainable forest management and planning or optimizing the use of timber, for example. Terrestrial laser scanning (TLS) can be used for measuring tree and forest attributes in very high detail. The study aims at characterizing changes in individual tree attributes (e.g., stem volume growth and taper) during a nine year-long study period in boreal forest conditions. TLS-based three-dimensional (3D) point cloud data were used for identifying and quantifying these changes. The results showed that observing changes in stem volume was possible from TLS point cloud data collected at two different time points. The average volume growth of sample trees was $0.226 \mathrm{~m}^{3}$ during the study period, and the mean relative change in stem volume was $65.0 \%$. In addition, the results of a pairwise Student's t-test gave strong support ( $p$-value 0.0001) that the used method was able to detect tree growth within the nine-year period between 2008-2017. The findings of this study allow the further development of enhanced methods for TLS-based single tree and forest growth modeling and estimation, which can thus improve the accuracy of forest inventories and offer better tools for future decision-making processes.
\end{abstract}

Keywords: tree stem volume; tree growth; terrestrial laser scanning; ground-based LiDAR; forest inventory; stem taper

\section{Introduction}

Tree growth is a result of an increase in the length, diameter, and thickness of tree stem, roots, and branches, leading to changes in the size and form of the tree [1]. Research has shown that there are several factors, both genetic and environmental, that affect tree growth. For instance, genetic background, climate, altitude, soil, topographical factors, and competition, as well as damages caused by storms, insects, and diseases, among other factors, have influence on tree growth [2-14]. Tree growth can be determined through changes in the most typical tree attributes such as diameter at breast height $(D B H)$ and height $(h) . D B H$ is the most basic and the most prevalent tree attribute, and is defined as the 
outside-bark stem diameter measured at 1.3-m height $[1,15]$. However, a diameter can be measured from any height along the stem. Tree $h$ is the distance between the base and the top of a standing tree [1]. Measures of tree $D B H$ and $h$ are used separately or together in addition with tree species in estimating other important single-tree attributes such as the cross-sectional area, stem volume, or biomass of a tree [16-18]. Changes in height-specific diameters and $h$ are the most important factors when determining the increment in stem volume or biomass, especially with coniferous trees in question. Periodic measurements of $D B H$ and $h$ are used when estimating the growth of the stem volume, basal area, or cross-sectional area [1].

Stem form and size determine the timber assortments that can be sawn from each stem. Thus, growth-induced changes in stem form and size affect their availability [19,20]. Sustainable forest management is an important topic both for economical or environmental viewpoints. Irrespective of the goals of forest management, there is a constant need for more accurate and up-to-date information on forest resources, such as the amount of available timber, forest growth, amount of biomass, and carbon sequestration. Changes in climate have altered the growth conditions of trees [21]. Also, the risk for snow, wind, and insect damages has been expected to increase due to climate change [22,23]. Forest structure, tree species, and stem form affect how the trees tolerate wind and snow conditions. Research has shown that surroundings and stem form, among other factors, affect the susceptibility to snow or wind damage [24]. In order to be able to deepen the knowledge of tree growth pattern, methods for measuring changes in tree from and size are required.

There are some methods that have traditionally been used for determining the tree growth. Measuring $\mathrm{DBH}$ and $h$ from the beginning and the end of a study period provides information about past growth and allows estimating the change of biomass or stem volume (see, e.g., [16-18]). Both DBH and $h$ measurements can be easily repeated. Thus, through relying on caliper and clinometer, traditional field measurements provide a relatively simple way of investigating tree growth. Increased accuracy and a higher level of detail can be achieved by using dendrometer bands for measuring small-scale diameter growth, even in short time intervals [25]. Also, several other methods for micro-scale diameter growth measurements have been introduced by, e.g., [26-31]. However, one-time measurements of tree $D B H$ or $h$ as well as dendrometer measurements do not provide information about the growth environment of a tree and the possible changes therein. However, the use of follow-up measurements on fixed sample plots (including, e.g., tree maps) allows following the changes that have happened within small-scale tree communities.

If earlier measurements are not available, increment measurements can be used for providing information about tree growth. For measuring diameter growth, either increment borings or cross-sectional cuts can be used (see, e.g., [1]). The annual increment can be measured from growth rings for any time period, as far as annual growth is detectable for the tree species in question. However, increment measurements that require boring or cross-sectional cuts are destructive methods. Boring damages the stem bark, exposing the tree to pathogens, whereas for collecting cross-sectional cuts, the tree is felled and cut into sections. Yet, as stem analysis requires that the tree is cut, it is not a feasible method for large-scale growth monitoring. Hence, other methods are needed for that purpose.

Terrestrial laser scanning (TLS) is a relatively new method in forest inventory. The first studies related to forest sciences are from the early 2000s [32]. TLS creates three-dimensional (3D) data that can be further processed and used for measuring, e.g., stem attributes. TLS enables measurements at millimeter scale without damaging trees, which separates it from the several other methods that are used for growth measurements. Maintaining trees undamaged can be seen as an important aspect as such. TLS has already been used for measuring single-tree attributes such as diameter along the stem and tree height [20,33-39] as well as stem volume [40-44], biomass [45-48], and stem taper [34,37,49]. Yet, detecting tree height precisely enough for operational needs has not yet reached an adequate level (e.g., [50]) and other solutions for measuring $h$ may be needed. Although several studies concentrate on measuring single-tree attributes by means of TLS, there are few studies that also cover the measurement of tree growth and change in stem form by using TLS. Sheppard et al. [51] were able to detect volume 
growth and the effects of pruning on the total volume for wild cherry (Prunus avium L.) over a two-year period. Kaasalainen et al. [52] were able to discover growth and changes in the structure of trees with repeated scans during a three-year period. Mengesha et al. [53] reported that multi-temporal TLS data enabled the accurate estimation of stem volume growth. Multi-temporal TLS data have also been used for modeling changes in above-ground biomass [54] and detecting changes in forest structure [55].

According to previous studies, TLS-based methods have reached at least a similar level of accuracy as traditional field measurements when measuring tree attributes [32,56]. The objective of this study is to study the changes in stem volume and stem taper of individual trees within a nine year-long study period. Stem volume is estimated from point clouds that have been created by collecting TLS data from sample plots at two different time points in 2008 and 2017. Based on our knowledge, the follow-up period of nine years is longer than what has been used in earlier TLS-based growth studies, and thus this experiment will improve the overall understanding and produce new information on the potential of the methods for future research. In addition to the growth of the stem volume, we will investigate how stem attributes describing the taper respond to tree growth at the tree level. This study contributes to characterizing tree growth and changes in the stem taper in the natural environment of a boreal forest, and thus provides improved estimates of forest resources. As a result, new opportunities for the field of measuring tree and forest growth will be revealed.

\section{Materials and Methods}

\subsection{Study Area}

The study area is located in Nuuksio National Park, southern Finland $\left(60^{\circ} 30^{\prime} \mathrm{N}, 24^{\circ} 52^{\prime} \mathrm{E}\right)$, which is approximately $30 \mathrm{~km}$ west of Helsinki (Figure 1). The total area of the national park is $53 \mathrm{~km}^{2}$ and it consists of large forest areas and several lakes. The elevation in the area varies from $27 \mathrm{~m}$ to $114 \mathrm{~m}$ above sea level. The dominant tree species in the area are Scots pine (Pinus sylvestris L.) and Norway spruce (Picea Abies (L.) H. Karst.), but mixed stands with broadleaved species also exist. The site type varies from groves to barren heaths and rocky hilltops.

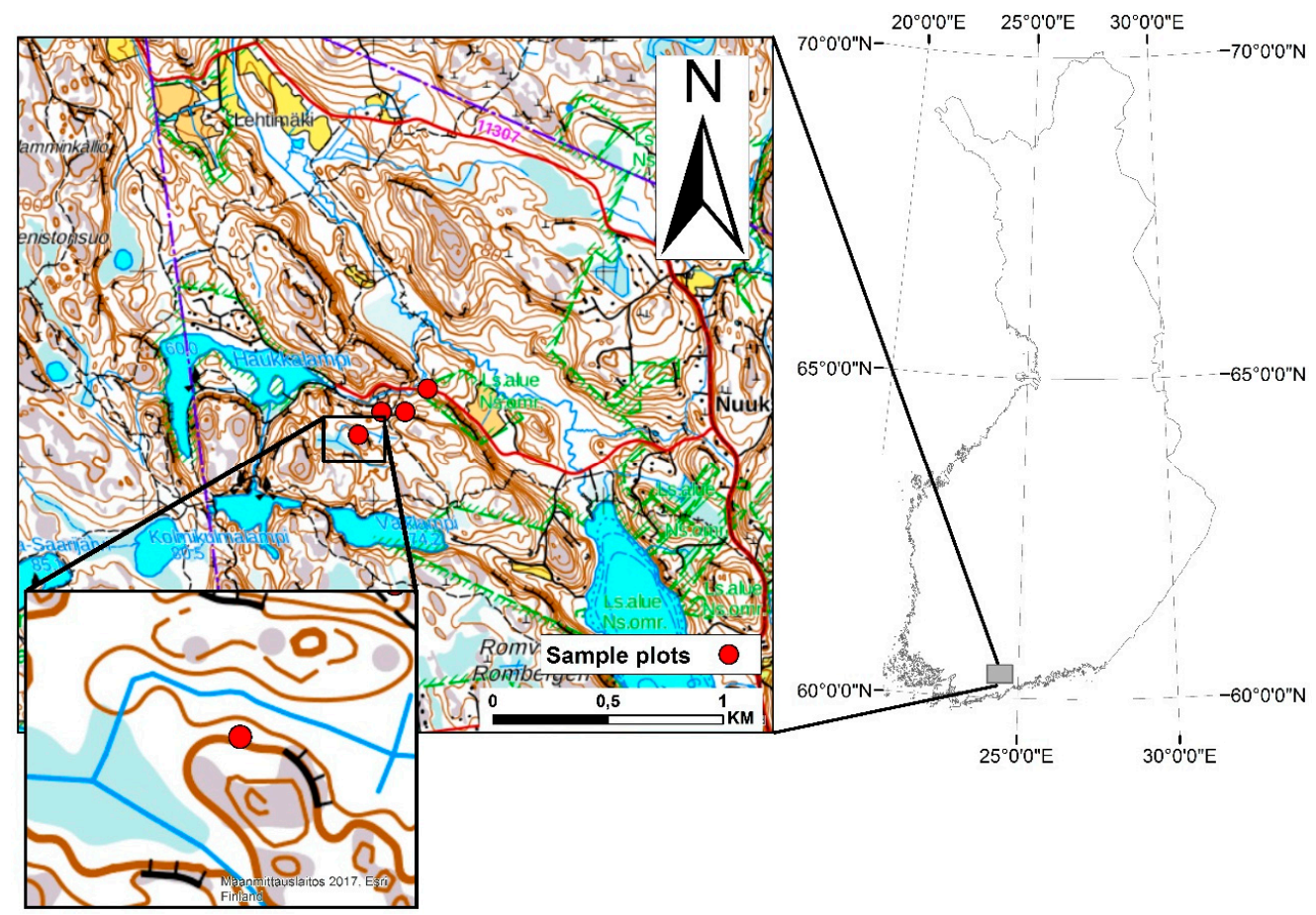

Figure 1. The location of study area in Nuuksio National Park in southern Finland. The location of all four sample plots is shown in the map on the left. A closer view of the terrain is given in the zoomed-in map, which represents one of the sample plots. 
A systematic network of sample plots was established in Nuuksio National Park in 2008 with fixed plot intervals of $100 \mathrm{~m}$. Lake Haukkalampi was used as the center point of the plot network, since it was known that there was a variety of forests on a small area around the lake. In total, 216 plots were included in the sample plot network and measured in the field to serve as reference primarily for airborne laser scanning research [57]. From the whole sample, eight plots best representing the overall variation of the study area were selected for TLS measurements. These plots were subject to a field control again in 2017. Four of the sample plots had remained undisturbed since the first TLS measurements and were re-scanned for this study.

The four plots were located within a 1-km radius to each other. All of the plots were located on mineral soils, but represented different types of forests varying from sub-xeric to herb-rich heath forests. Species composition was mainly coniferous, with Scots pine and Norway spruce as the main tree species, but a mixture of deciduous trees also existed on the plots. The development class of the plots varied from young thinning stands to mature plots. The sample plots were circular with a radius of $7.98 \mathrm{~m}$, and all the trees with a $D B H$ of at least $5 \mathrm{~cm}$ were measured.

\subsection{Sample Plot Measurements}

All the measurements were performed twice in this study to provide two-date data from the sample plots. First measurements were done in spring $2008\left(T_{1}\right)$ and repeated in spring $2017\left(T_{2}\right)$. The $T_{2}$ measurements followed the same principal that was used in $\mathrm{T}_{1}$. Both traditional field measurements and TLS were performed on each plot. For TLS, phase-shift scanner Leica HSD6100 (Leica Geosystems AG, Heerbrugg, Switzerland; now Hexagon AB, Stockholm, Sweden) was used with high-resolution settings (i.e., $\sim 10,000 \mathrm{pts} / \mathrm{m}^{2}$ and $6.3-\mathrm{mm}$ spacing at $10-\mathrm{m}$ distance from the scanner). The positional accuracy of the scanner was $5 \mathrm{~mm}$ on a single-measurement range: from 1 to 25 meters. The scan set-up consisted of a central scan at the plot center, and from four to six additional scans around the plot. The number of additional scans varied between the plots based on the stem density and other factors affecting the visibility in the plot (i.e., undergrowth, dominant tree species, age of the stand). Artificial reference targets were spread out on the sample plot and used for co-registering the scans to a single 3D point cloud covering the entire sample plot. Similar scanning set-ups and settings were used both in $\mathrm{T}_{1}$ and $\mathrm{T}_{2}$.

In addition to TLS measurements, species, the $D B H$ and $h$ of all the trees on the plot were recorded during the field measurements. $h$ was measured with a Haglöf Vertex Ultrasonic (Haglöf Sweden AB, Långsele, Sweden) clinometer on a 0.1-meter scale. Before measuring $h$, the clinometer was calibrated to current weather conditions.

All the trees from the sample plots with $D B H \geq 5 \mathrm{~cm}$ in 2008 and which were defined as living still in 2017 were included the study. Finally, from the four sample plots, a total of 35 trees were available for analysis. Of the 35 trees, 10 were Scots pines, 14 were Norway spruces, five were silver birches (Betula pendula Roth), and five were other deciduous trees (one maple (Acer Platanoides L.), two aspens (Populus tremula L.), and three lime trees (Tilia cordata Mill.)). Tree sizes on sample plots varied in DBH from $6.2 \mathrm{~cm}$ to $50.7 \mathrm{~cm}$, and in $h$ from $5.0 \mathrm{~m}$ to $34.0 \mathrm{~m}$, according to the measurement data from 2008 (Table 1).

Table 1. Summary of plot-level variables. Number of trees, plot-level mean, minimum, and maximum values for diameter at breast height $(D B H)$ and height $(h)$ in $\mathrm{T}_{1}$.

\begin{tabular}{cccccccc}
\hline \multirow{2}{*}{ Plot } & \multirow{2}{*}{$\begin{array}{c}\text { Number } \\
\text { of Trees, } \boldsymbol{n}\end{array}$} & \multicolumn{3}{c}{$\mathbf{D B H}, \mathbf{c m}$} & \multicolumn{3}{c}{$\boldsymbol{h}, \mathbf{m}$} \\
\cline { 3 - 8 } & & Mean & Min & Max & Mean & Min & Max \\
\hline 1 & 10 & 10.5 & 7.6 & 14.5 & 10.2 & 7.1 & 12.8 \\
2 & 6 & 30.7 & 26.8 & 39.0 & 26.9 & 24.7 & 29.7 \\
3 & 9 & 22.1 & 7.2 & 45.0 & 19.4 & 5.6 & 31.0 \\
4 & 10 & 31.2 & 6.2 & 50.7 & 25.4 & 5.0 & 34.0 \\
\hline Total & 35 & 22.8 & 6.2 & 50.7 & 19.8 & 5.0 & 34.0 \\
\hline
\end{tabular}




\subsection{Data Processing and Measurement Method}

The TLS data from individual scans were co-registered in the $Z+F$ LaserControl program (Zoller and Fröhlich GmbH, Wangen im Allgäu, Germany) using artificial reference targets. Trees were identified from the point clouds using tree maps that were created from the data. After this, tree-specific point clouds were extracted with TerraScan software (Terrasolid, Helsinki, Finland). The TLS data processing was done following the same steps for data from both time points $\left(\mathrm{T}_{1}\right.$ and $\left.\mathrm{T}_{2}\right)$ of the study.

Diameters along the stem (i.e., taper curves) for each tree were determined from the tree-specific point clouds by fitting circles with $10-\mathrm{cm}$ intervals along a stem. The method is described in more detail in Saarinen et al. [40]. Stem volumes were estimated from the taper curve using Huber's formula following the method of Saarinen et al. [40] with the exception that field-measured $h$ was used instead of TLS-derived $h$. The main reason for this was that several studies have shown TLS to underestimate tree height $[32,37,58]$, whereas clinometer measurements have provided more reliable results (see, e.g., [59]).

\subsection{Estimating Attributes for Individual Trees}

Several attributes describing tree size and stem taper were calculated for all the 35 sample trees by using TLS-based attributes. The attributes have been developed to describe the stem form and were thus suitable for investigating changes between $\mathrm{T}_{1}$ and $\mathrm{T}_{2}$.

Stem taper is defined as the difference between diameter measurements from two pre-determined heights (Equation (1)):

$$
T A P=D B H-d_{6.0}
$$

where TAP is the stem taper, $D B H$ is the diameter at breast height, and $d_{6.0}$ is the diameter at 6.0-meter height. Calculating the difference between TAP values of $\mathrm{T}_{1}$ and $\mathrm{T}_{2}$ shows how the growth pattern of the tree has changed over time.

Cylindrical form factor $(f)$ describes the relationship between the stem and a cylinder whose diameter equals the $D B H$ and the height $(h)$ of the tree [1]. It is the most commonly used version of form factors, and is also known as the breast height form factor (Equation (2)):

$$
f=\frac{V o l}{g h}
$$

where $\mathrm{Vol}$ is the stem volume of the tree, $g$ is the basal area of the tree at breast height, and $h$ is the height of the tree.

The ratio between $D B H$ and some other diameter along the stem is known as the form quotient. The normal form quotient [60] was used in this study to describe the ratio between $D B H$ and diameter at one-half of the total tree height $\left(d_{0.5 h}\right)$ (Equation (3)):

$$
q_{0.5}=\frac{d_{0.5 h}}{D B H}
$$

where $q_{0.5}$ is the normal form quotient, $D B H$ is the diameter at breast height, and $d_{0.5 h}$ is the diameter at one-half of the total tree height. For both $f$ and $q_{0.5}$, a value equal to one would mean that the stem form is equal to a cylinder. Thus, an increase in $f$ or $q_{0.5}$ means that the stem form is developing toward a cylindrical form.

Stem slenderness can be evaluated with the height-to-diameter ratio (HDR) (Equation (4)):

$$
H D R=\frac{h}{D B H}
$$

where $h$ is the height of the tree and $D B H$ is the diameter at breast height. 


\subsection{Evaluating the Method's Suitability for Detecting Change in Stem Volume and Stem Taper}

The difference in stem volume estimates was evaluated between $\mathrm{T}_{1}$ and $\mathrm{T}_{2}$. Statistical significance of the detected change was evaluated using Student's pairwise $t$-test. For stem volume, the null hypothesis stated that the method wouldn't be able to detect tree growth within the period between $\mathrm{T}_{1}$ and $\mathrm{T}_{2}$. For the other stem attributes, Student's pairwise $t$-test was used to evaluate whether a statistically significant change had occurred in TAP, $f, q_{0.5}$, or HDR. For these attributes, the null hypothesis was formulated that "No change in stem form attribute has occurred within the period between $T_{1}$ and $T_{2}$ ". In addition to statistical analysis, the change between $T_{1}$ and $T_{2}$ was evaluated by investigating the amount of the change among the sample trees. We also studied whether the potential change was similar for all the tree sizes and species, or whether some differences could be found.

For all the stem attributes, the absolute change between $T_{1}$ and $T_{2}$ was calculated by determining the difference between the attribute values (Equation (5)):

$$
\Delta X=X_{T 2}-X_{T 1}
$$

where $X_{T 1}$ is the value of an attribute in $T_{1}$, and $X_{T 2}$ is the value of an attribute in $T_{2}$.

The relative change in stem attributes between $T_{1}$ and $T_{2}$ was calculated by dividing the absolute change with the original attribute value from $\mathrm{T}_{1}$ (Equation (6)):

$$
\Delta X \%=\frac{\Delta X}{X_{T 1}}
$$

where $\Delta X$ is the absolute change of an attribute, and $X_{T 1}$ is the value of an attribute in $T_{1}$.

The change in stem diameters between $\mathrm{T}_{1}$ and $\mathrm{T}_{2}$ was also evaluated visually by plotting both taper curves simultaneously. For each sample tree, the changes in the stem form could be viewed throughout the whole tree from the taper curve plots. Taper curve plots gave additional information that was used in support when analyzing the detected change in stem attributes. For this study, three sample trees were selected for use as examples of visualization. The first selected tree was a Norway spruce with a $D B H$ of $39.0 \mathrm{~cm}$ and a $h$ of $28.6 \mathrm{~m}$. Considering the attributes within the whole sample, the tree was determined as a "large coniferous tree". The second example was a Scots pine with a $D B H$ of $11.4 \mathrm{~cm}$ and a $h$ of $11.2 \mathrm{~m}$ in 2008 , which was classified as a "small coniferous tree". The third example tree was an aspen with a DBH of $49.2 \mathrm{~cm}$ and a $h$ of $32.6 \mathrm{~m}$. It was determined as an example for a "large broadleaved tree".

\section{Results}

Measurement results for the sample tree species, $D B H, h, V o l, T A P, f, q_{0.5}$, and $H D R$ from both $\mathrm{T}_{1}$ and $\mathrm{T}_{2}$ are presented in Table S1. The mean Vol of sample trees increased from $0.611 \mathrm{~m}^{3}$ in $\mathrm{T}_{1}$ to 0.838 $\mathrm{m}^{3}$ in $\mathrm{T}_{2}$. The minimum and maximum $\mathrm{Vol}$ were $0.013 \mathrm{~m}^{3}$ and $2.558 \mathrm{~m}^{3}$, and $0.013 \mathrm{~m}^{3}$ and $3.925 \mathrm{~m}^{3}$ for $T_{1}$ and $T_{2}$, respectively. The average TAP for the sample trees was $4.5 \mathrm{~cm}$ in $T_{1}$ and $3.6 \mathrm{~cm}$ in $T_{2}$, indicating a smaller tapering in $\mathrm{T}_{2}$. The average values of $f, q_{0.5}$, and $H D R$ were $0.47,0.64$, and 0.92 , in $\mathrm{T}_{1}$, and $0.50,0.71$, and 0.93 in $\mathrm{T}_{2}$, respectively.

The change in stem attributes during the study period is presented in Table S2. Positive values indicate the increase of an attribute during the study period, whereas negative values indicate a decrease in the attribute. The relative growth in Vol varied from $4.3 \%$ to $240.3 \%$ during the study period. Also, the results of a pairwise Student's t-test gave strong evidence ( $p$-value 0.0001) against the null hypothesis, which means that the method was able to detect stem volume growth within the nine-year study period. In addition, Table 2 presents the pairwise Student's t-test results for evaluating the null hypothesis "No change in stem form attribute has occurred within the period between $\mathrm{T}_{1}$ and $\mathrm{T}_{2}$ " in TAP, $f, q_{0.5}$, and HDR. For both TAP and $q_{0.5}$, a null hypothesis could be rejected with $p$-values of 0.0023 and 0.0081 , respectively. Whereas for $f$ and $H D R$, the null hypothesis stood due to respective $p$-values of 0.0589 and 0.7606 . Based on this, changes in TAP and $q_{0.5}$ did happen during the study 
period, whereas the stem form didn't change significantly when considering the relationship between $h$ and $D B H(H D R)$ or $V o l$ in relation to the basal area and $h(f)$.

Table 2. The $p$-values of Student's pairwise $t$-test, where it was tested whether the stem form attributes have changed during the study period. The null hypothesis stated that no change in stem form attribute has occurred within the period between $\mathrm{T}_{1}$ and $\mathrm{T}_{2}$. For tapering $(T A P)$ and normal form quotient $\left(q_{0.5}\right)$, the null hypothesis could be rejected, and for the cylindrical form factor $(f)$ and height-to-diameter ratio (HDR), it was upheld.

\begin{tabular}{ccccc}
\hline & TAP & $f$ & $q_{0.5}$ & HDR \\
\hline$p$-value & 0.0023 & 0.0589 & 0.0081 & 0.7606 \\
\hline
\end{tabular}

The TAP mainly decreased for most of the sample trees during the study period, but there were also a few trees for which TAP had increased. The values of $f$ and $q_{0.5}$ had mainly a minor increase among the sample trees, even though there were differences between individual trees with $\Delta f$ ranging from $-29 \%$ to $59 \%$ and $\Delta q_{0.5}$ ranging from $-35 \%$ to $142 \%$. For $H D R$, the change was only a few percentage points for most of the sample trees. However, as the changes were both positive and negative, there was no clear trend in the change. The mean change between $T_{1}$ and $T_{2}$ per sample tree was also calculated for $\mathrm{Vol}$, and other attributes were used for describing the stem taper. These results are presented in Table 3. The mean increment in $\mathrm{Vol}$ was $0.226 \mathrm{~m}^{3}$, which corresponded to the mean relative change of $65.0 \%$. TAP decreased on average $0.8 \mathrm{~cm}(-13 \%)$, which means that the absolute diameter growth at the height of $6.0 \mathrm{~m}$ was at a little higher rate than that at the breast height during the study period.

Table 3. The change in stem attributes: the mean, standard deviation, and mean of relative change per sample tree in stem volume $(\triangle V o l)$, tapering $(\triangle T A P)$, cylindrical form factor $(\Delta f)$, normal form quotient $\left(\Delta q_{0.5}\right)$, and height-to-diameter ratio $(\triangle H D R)$ for all the sample trees used in the study.

\begin{tabular}{lccccc}
\hline & $\boldsymbol{\Delta} \mathbf{V o l}, \mathbf{m}^{\mathbf{3}}$ & $\boldsymbol{\Delta} \mathbf{T A P}, \mathbf{c m}$ & $\boldsymbol{\Delta f}$ & $\boldsymbol{\Delta} \boldsymbol{q}_{\mathbf{0 . 5}}$ & $\boldsymbol{\Delta H D R}$ \\
\hline Mean & 0.226 & -0.8 & 0.03 & 0.07 & 0.01 \\
\hline Std.dev & 0.298 & 1.5 & 0.09 & 0.14 & 0.10 \\
\hline Mean relative change & $65.0 \%$ & $-13 \%$ & $9 \%$ & $15 \%$ & $1 \%$ \\
\hline
\end{tabular}

The species-specific relative change in $\mathrm{Vol}$ (i.e., growth) between $\mathrm{T}_{1}$ and $\mathrm{T}_{2}$ was $125 \%$ for Scots pine, $44 \%$ for Norway spruce, $21 \%$ for Silver birch, and $52 \%$ for the other broadleaved species in the study. For Scots pine and Norway spruce, the relative change in TAP was negative (-34\% and $-12 \%$, respectively) whereas TAP was positive for both Silver birch and other broadleaved trees $(9 \%$ and $3 \%$, respectively). The value of $f$ increased for all the tree species (Scots pine 9\%, Norway spruce $9 \%$, Silver birch $18 \%$, and other broadleaved trees $1 \%$ ) similarly to $q_{0.5}(13 \%, 15 \%, 35 \%$, and $4 \%$, respectively). The HDR had a marginal relative change for all the species $(6 \%,-2 \%,-1 \%$, and $1 \%)$ during the nine-year study period (Table 4).

Table 4. Species-specific mean attributes in $\mathrm{T}_{1}$ and change in species-specific stem attributes. The relative change in stem volume $(\triangle V o l)$, tapering $(\triangle T A P)$, cylindrical form factor $(\Delta f)$, normal form quotient $\left(\Delta q_{0.5}\right)$, and height-to-diameter ratio $(\triangle H D R)$ for four different classes of tree species. Also, mean diameter at the breast height $(D B H)$, tree height $(h)$, and stem volume based on measurements from 2008 are given in the table to describe the tree species classes in detail.

\begin{tabular}{|c|c|c|c|c|c|c|c|c|}
\hline Species Class & $\begin{array}{c}\text { Mean } D B H \\
(\mathrm{~cm}) 2008\end{array}$ & $\begin{array}{l}\text { Mean } h \\
\text { (m) } 2008\end{array}$ & $\begin{array}{l}\text { Mean Vol } \\
\left(\mathrm{m}^{3}\right) 2008\end{array}$ & $\begin{array}{l}\Delta \mathrm{Vol} \\
(\%)\end{array}$ & $\begin{array}{c}\Delta T A P \\
(\%)\end{array}$ & $\begin{array}{c}\Delta f \\
(\%)\end{array}$ & $\begin{array}{l}\Delta q_{0.5} \\
(\%)\end{array}$ & $\begin{array}{c}\Delta H D R \\
(\%)\end{array}$ \\
\hline Pinus sylvestris, $L$. & 10.5 & 10.2 & 0.049 & $125 \%$ & $-34 \%$ & $9 \%$ & $13 \%$ & $6 \%$ \\
\hline Picea Abies (L.) H. Karst & 27.3 & 23.8 & 0.796 & $44 \%$ & $-12 \%$ & $9 \%$ & $15 \%$ & $-2 \%$ \\
\hline Betula pendula & 34.0 & 28.5 & 1.070 & $21 \%$ & $9 \%$ & $18 \%$ & $35 \%$ & $-1 \%$ \\
\hline Other broadleaved & 23.8 & 19.1 & 0.735 & $52 \%$ & $3 \%$ & $1 \%$ & $4 \%$ & $1 \%$ \\
\hline
\end{tabular}


In Figure 2, taper curves from both $\mathrm{T}_{1}$ and $\mathrm{T}_{2}$ are plotted to visualize and describe the growth and development of stem form for all three example trees.
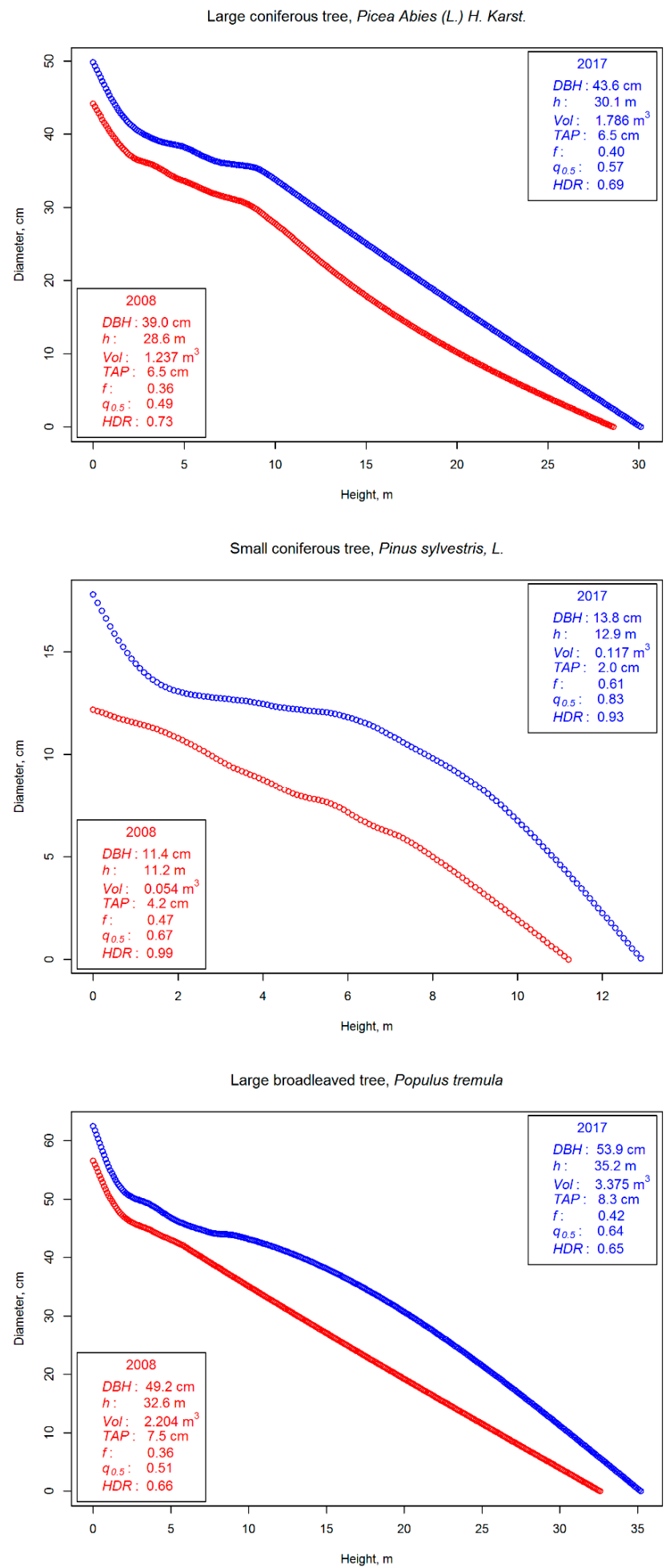

Figure 2. Graph describing the stem form of Norway spruce (Picea abies (L.) H. Karst.) (large coniferous tree), Scots pine (Pinus sylvestris L.) (small coniferous tree), and Aspen (Populus tremula) (large broadleaved tree). The red circles represent the estimated stem form in 2008, and the blue circles are drawn to represent the stem form of the same tree in 2017. The change in stem form can be viewed by comparing the red and blue graphs to each other. The attributes used to describe the tree and its stem form $(D B H, h, V o l, T A P, f$, $q_{0.5}$, and HDR) are shown in separate legends both for 2008 (red) and 2017 (blue). 


\section{Discussion}

In total, 35 trees from four sample plots were measured at two different time points to investigate whether measuring the change in stem volume and other stem attributes is possible by using two-date TLS data. The aim was also to find new opportunities and solutions for detecting the tree growth. The results showed that it was possible to identify stem volume growth with TLS data acquired at two points of time, in 2008 and 2017. Additionally, changes were discerned in attributes characterizing stem form, and gave evidence that TLS point clouds can be used in follow-up measurements for determining stem volume growth. The results provided further information for developing new tools for forest growth research, where traditional ways of measurement are still widely in use.

Tree stem volume was estimated for all trees combining the method presented in Saarinen et al. [40] and $h$ measured with Vertex clinometer. Both $D B H$ and $h$ for all the 35 sample trees increased between $\mathrm{T}_{1}$ and $\mathrm{T}_{2}$. Based on the results, the relative $\mathrm{Vol}$ growth of sample trees had large variation during the study period (from $4.3 \%$ to $240.3 \%$ ). Since the sample trees were located in diverse growth environments and represent various species as well as size and age classes, the level of volume growth was expected to vary (e.g., [12,61]). Even though the accuracies of TLS-based DBH and Vol estimation as well as field measured $h$ are well known [33-40,42-44], more studies with larger amount of sample trees would be needed for further examining the volume growth detection.

Except for the rather clear change in stem volume, there were no equally clear trends in the other attributes describing the stem form of sample trees. However, according to Student's pairwise t-test, a statistically significant change could be detected for both TAP and $q_{0.5}$, whereas a similar change in HDR or $f$ was not observed. On average, TAP decreased for the sample trees. When investigating the species-specific change, it was notable that TAP decreased for coniferous species, but increased for broadleaved sample trees. The largest decrease in TAP was detected for Scots pine trees. However, it needs to be pointed out that all Scots pine sample trees were relatively small and still in a younger development phase when compared to other sample trees. To be able to draw further conclusions about the change in tapering during the lifetime of a tree, a longer follow-up period with several measurements or more sample trees from various size and age classes would be required. Using TLS-based high-quality point clouds could be an option for re-considering the definition and measurement of stem tapering. For example, with the ability of observing the diameter at any height, tapering could be measured by comparing diameters from other heights than the traditional $1.3 \mathrm{~m}$ and $6.0 \mathrm{~m}$.

On average, the values of $q_{0.5}$ increased slightly. As DBH is in a divisor in the formula of $q_{0.5}$, it can be stated that diameter above the 1.3-meter height (i.e., for $q_{0.5}$, the height corresponding to $50 \%$ of the total tree height) had increased relatively more than the $D B H$. Also, if the absolute increase in $d_{6.0}$ is larger than in $D B H$, it causes TAP to decrease. Although small changes were detected also in $f$ and HDR, they were not statistically significant. Even though it can be stated that changes in stem form do happen, it is possible that no significant changes in HDR or $f$ should even be detected for all the trees during the study period. This is because until a certain point of development, both $D B H$ and $h$ increase as the tree grows [1]. However, it also needs to be noticed that the few exceptional observations in each TAP, $f, q_{0.5}$, and HDR could be caused by trees allocating their growth differently. For example, the location, the effect of surrounding trees, and other factors affecting the growth can lead to differences in increments of $D B H$ and $h$ [12-14]. Based on results in this study, further research on the effects of different growth conditions and development phases on stem form is needed to cover this issue more in detail.

There are several traditional methods for monitoring tree growth. Measuring $D B H$ with calipers or diameter tape and $h$ with a clinometer provides precise results for current tree attributes [59]. By using repeated measurements, the measurements can also be used for monitoring tree growth [62]. Dendrometer bands can be used for following the diameter growth of a tree in real time, and the measurements can even be completed on several heights at the same time (e.g., [25,31]). These methods can provide exact information about tree growth. However, they are relatively slow, laborious, and thus expensive for collecting large amounts of data. In addition to on-top-of-the-bark measurements, 
destructive methods such as increment borings or cross-sectional cuts of stems have been used for increment measurements. In contrast to these methods, TLS measurements are non-destructive for trees and the growth environment.

When using the traditional methods, investigation and comparison between the present and the past can only be done by using the recorded attributes from the earlier measurements. Thus, no additional information can be gained from the past status. Even though TLS-based measurements are somewhat time consuming both in the field and in the data-processing phase, the resulting point clouds provide the possibility of measuring numerous attributes of the trees [32,56]. For example, taper curves or stem models can be created for any tree [36]. An additional strength of TLS-based measurements is that once the point cloud has been created, it is always available for future use, and new attributes can be measured if needed.

Regardless of the practicality of the traditional methods, there are many factors that support the use of TLS-based growth measurements. Sheppard et al. [51] and Kaasalainen et al. [52] have already used TLS-based point clouds to detect tree growth in a shorter time period than the nine years used in this study. In addition, several studies have shown that TLS-based measurements provide accurate information about tree diameter [36,37], and that it has been successfully used for measuring stem volume $[40,44]$ and biomass [46-48]. However, measuring $h$ remains a challenge for TLS and limits its use, especially within tall and dense stands where branches and crowns limit the visibility of tree tops $[40,44,63]$. Due to the above-mentioned possibilities and limitations, a combination of traditional field measurements and 3D point cloud data was used successfully in this study to detect tree growth and change in stem form. The $h$ was measured by using a Vertex clinometer, and all the other attributes were extracted from point clouds provided by TLS. The use of 3D point clouds enables the measurement of a wider range of attributes, such as evaluating the growth environment and changes in stand density, for example [55,64], which is not possible from the traditional data without additional measurements. Also, point clouds enable returning back in time to do further measurements from old datasets. As noted in this study, such an approach could help in the further investigation of small-scale between-tree variation in growth.

However, with the TLS technique still not capable of providing accurate estimates of $h$ (e.g., [32]), supplementary solutions are needed. In this study, field-measured $h$ was used in the estimations, but measuring $h$ from airborne laser scanning data or predicting $h$ with models could also be utilized for the same purposes [65]. Also, considering tree growth and changes in stem form, the detection of tree growth could be done by concentrating only on changes in small parts of the stem, and scale up the measurements for deriving the growth of the whole tree.

The results of this study showed that the volume growth can be detected by using TLS-based measurements. It was also possible to follow how the stem attributes changed during the study period. When utilized in further research, the findings of this study will give new important information and support for creating more accurate forest resource estimates, and thus help the decision makers find the best possible solutions.

\section{Conclusions}

Measuring and allocating tree growth has been challenging by the means of traditional field measurements, although it is one of the most important attributes. When applied to large areas, it affects the correctness of calculations related to forest resource planning and carbon balance. This study demonstrated the capability of TLS data for characterizing individual tree growth, but also changes in stem form through simple attributes describing stem form. Two-date TLS-based point clouds provided an assessment of volume growth and changes in stem form. Even if the sample trees used in this study covered only a few tree species and size classes, the findings of this study shed new light on methods for more accurate tree growth detection. The possibilities of utilizing TLS point clouds for providing new attributes for characterizing stem form and its changes is an interesting area for further research. 
Improved knowledge about tree growth is one of the key issues when producing accurate information for the needs of forest management planning or even climatic modeling.

Supplementary Materials: The following are available online at http://www.mdpi.com/1999-4907/10/5/382/s1, Table S1: Stem attributes from 2008 and 2017. Trees are sorted based on plot number, tree species, and DBH in 2008 , starting from the smallest tree. Diameter at breast height $(D B H)$, tree height $(h)$, stem volume $(V o l)$, tapering $(T A P)$, cylindrical form factor $(f)$, normal form quotient $\left(q_{0.5}\right)$, and the height-to-diameter ratio (HDR) for each tree are reported from measurements for both 2008 and 2017, Table S2: The change in stem attributes between 2008 and 2017. Variables describing stem form are presented both in absolute and relative values. Trees are presented in the same plot, species, and size-based order as in Table S1. Change in stem volume $(\Delta V o l)$, tapering $(\triangle T A P)$, cylindrical form factor $(\Delta f)$, normal form quotient $\left(\Delta q_{0.5}\right)$, and height-to-diameter ratio $(\Delta H D R)$ are given in original units and the percentage change is given in parentheses.

Author Contributions: V.L., N.S., V.K., and M.V. planned the study design together with M.H. and J.H. V.L., N.S., and V.K. were the main authors. V.L. was responsible of the data processing and analysis. M.V., H.K., A.K., and T.T. collected the reference and TLS data together with V.L. Ideas of H.K. and A.K. were utilized for the study design, TLS data collection, and processing. The TLS instrument was provided by the Finnish Geospatial Research Institute. The paper was improved by the contributions of all the authors at various stages of the analysis, writing, and review processes.

Funding: This research was funded by the Academy of Finland through the Centre of Excellence in Laser Scanning Research, grant number 2721955 and the Ministry of Agriculture and Forestry Finland through Finnish Government Key Project "Puu liikkeelle ja uusia tuotteita metsästä" ("Wood on the move and new products from forest").

Conflicts of Interest: The authors declare no conflict of interest.

\section{References}

1. Husch, B.; Beers, T.W.; Kershaw, J.A. Forest Mensuration, 4th ed.; John Wiley \& Sons: Hoboken, NJ, USA, 2003; p. 443.

2. King, G.M.; Gugerli, F.; Fonti, P.; Frank, D.C. Tree growth response along an elevational gradient: Climate or genetics? Oecologia 2013, 173, 1587-1600. [CrossRef]

3. Bradshaw, H.D., Jr.; Stettler, R.F.; Bradshaw, H.D. Molecular Genetics of Growth and Development in Populus. IV. Mapping Qtls with Large Effects on Growth, Form, and Phenology Traits in a Forest Tree. Genetics 1995, 139, 963-973.

4. Alberto, F.J.; Aitken, S.N.; Alía, R.; González-Martínez, S.C.; Hänninen, H.; Kremer, A.; Lefèvre, F.; Lenormand, T.; Yeaman, S.; Whetten, R.; et al. Potential for evolutionary responses to climate change-Evidence from tree populations. Chang. Boil. 2013, 19, 1645-1661. [CrossRef]

5. Mead, D.J.; Tamm, C.O. Growth and stem form changes in Picea abies as affected by stand nutrition. Scand. J. 1988, 3, 505-513. [CrossRef]

6. Cherubini, P.; Fontana, G.; Rigling, D.; Dobbertin, M.; Brang, P.; Innes, J.L. Tree-life history prior to death: Two fungal root pathogens affect tree-ring growth differently. J. Ecol. 2002, 90, 839-850. [CrossRef]

7. Dobbertin, M. Tree growth as indicator of tree vitality and of tree reaction to environmental stress: A review. Eur. J. 2005, 124, 319-333.

8. Lyytikäinen-Saarenmaa, P.; Tomppo, E. Impact of sawfly defoliation on growth of Scots pine Pinus sylvestris (Pinaceae) and associated economic losses. Bull. Èntomol. Res. 2002, 92, 137-140. [CrossRef]

9. Quine, C.P. Assessing the risk of wind damage to forests: Practice and pitfalls. In Wind and Trees; Coutts, M.P., Grace, J., Eds.; Cambridge University Press: Cambridge, UK, 1995; pp. 379-403.

10. Solberg, S.; Andreassen, K.; Clarke, N.; Tørseth, K.; Tveito, O.E.; Strand, G.H.; Tomter, S. The possible influence of nitrogen and acid deposition on forest growth in Norway. Ecol. Manag. 2004, 192, 241-249. [CrossRef]

11. Harper, J.L. Population Biology of Plants; The Blackburn Press: Caldwell, NJ, USA, 1977.

12. Coomes, D.A.; Allen, R.B. Effects of size, competition and altitude on tree growth. J. Ecol. 2007, 95, 1084-1097. [CrossRef]

13. Canham, C.D.; Lepage, P.T.; Coates, K.D. A neighborhood analysis of canopy tree competition: Effects of shading versus crowding. Can. J. 2004, 34, 778-787. [CrossRef]

14. Aakala, T.; Berninger, F.; Starr, M. The roles of competition and climate in tree growth variation in northern boreal old-growth forests. J. Veg. Sci. 2018, 29, 1040-1051. [CrossRef] 
15. Avery, T.E.; Burkhart, H.E. Forest Measurements; Waveland Press: Long Grove, IL, USA, 2015.

16. Repola, J. Biomass equations for birch in Finland. Silva Fenn. 2008, 42, 605-624. [CrossRef]

17. Repola, J. Biomass equations for Scots pine and Norway spruce in Finland. Silva Fenn. 2009, 43, $625-647$. [CrossRef]

18. Laasasenaho, J. Taper Curve and Volume Functions for Pine, Spruce and Birch; The Finnish Forest Research Institute: Helsinki, Finland, 1982.

19. Uusitalo, J. Pre-harvest measurement of pine stands for sawing production planning. Acta For. Fenn. 1997. [CrossRef]

20. Kankare, V.; Vauhkonen, J.; Tanhuanpää, T.; Holopainen, M.; Vastaranta, M.; Joensuu, M.; Krooks, A.; Hyyppä, J.; Hyyppä, H.; Alho, P.; et al. Accuracy in estimation of timber assortments and stem distribution-A comparison of airborne and terrestrial laser scanning techniques. ISPRS J. Photogramm. Sens. 2014, 97, 89-97. [CrossRef]

21. Lindner, M.; Maroschek, M.; Netherer, S.; Kremer, A.; Barbati, A.; Garcia-Gonzalo, J.; Seidl, R.; Delzon, S.; Corona, P.; Kolström, M.; et al. Climate change impacts, adaptive capacity, and vulnerability of European forest ecosystems. Ecol. Manag. 2010, 259, 698-709. [CrossRef]

22. Seidl, R.; Rammer, W.; Spies, T.A. Disturbance legacies increase the resilience of forest ecosystem structure, composition, and functioning. Ecol. Appl. 2014, 24, 2063-2077. [CrossRef]

23. Seidl, R.; Thom, D.; Kautz, M.; Martin-Benito, D.; Peltoniemi, M.; Vacchiano, G.; Wild, J.; Ascoli, D.; Petr, M.; Honkaniemi, J.; et al. Forest disturbances under climate change. Nat. Clim. Chang. 2017, 7, 395-402. [CrossRef]

24. Zubizarreta-Gerendiain, A.; Pellikka, P.; Garcia-Gonzalo, J.; Ikonen, V.-P.; Peltola, H. Factors affecting wind and snow damage of individual trees in a small management unit in Finland. Silva Fennica 2012, 46, 181-196. [CrossRef]

25. Liming, F.G. Homemade dendrometers. J. For. 1957, 55, 575-577.

26. Daubenmire, R.F. An Improved Type of Precision Dendrometer. Ecology 1945, 26, 97-98. [CrossRef]

27. Fritts, H.C.F; Edwin, C. A New Dendrograph for Recording Radial Changes of a Tree. Forest Science 1955, 1, $271-276$.

28. Impens, I.I.; Schalck, J.M. A Very Sensitive Electric Dendrograph for Recording Radial Changes of a Tree. Ecology 1965, 46, 183-184. [CrossRef]

29. Kinerson, R.S. A Transducer for Investigations of Diameter Growth. For. Sci. 1973, 19, 230-232.

30. Phipps, R.L.; Gilbert, G.E. An electric dendrograph. Ecology 1960, 41, 389-390. [CrossRef]

31. Reineke, L.H. A Precision Dendrometer. J. For. 1932, 30, 692-699.

32. Liang, X.; Kankare, V.; Hyyppä, J.; Wang, Y.; Kukko, A.; Haggrén, H.; Yu, X.; Kaartinen, H.; Jaakkola, A.; Guan, F.; et al. Terrestrial laser scanning in forest inventories. ISPRS J. Photogramm. Sens. 2016, 115, 63-77. [CrossRef]

33. Cabo, C.; Ordoñez, C.; López-Sánchez, C.A.; Armesto, J. Automatic dendrometry: Tree detection, tree height and diameter estimation using terrestrial laser scanning. Int. J. Appl. Earth Obs. Geoinformation 2018, 69, 164-174. [CrossRef]

34. Henning, J.G.; Radtke, P.J. Detailed Stem Measurements of Standing Trees from Ground-Based Scanning Lidar. Forest Science 2006, 52, 67-80.

35. Huang, H.; Li, Z.; Gong, P.; Cheng, X.; Clinton, N.; Cao, C.; Ni, W.; Wang, L. Automated Methods for Measuring DBH and Tree Heights with a Commercial Scanning Lidar. Photogramm. Eng. Sens. 2011, 77, 219-227. [CrossRef]

36. Liang, X.; Hyyppa, J. Automatic Stem Mapping by Merging Several Terrestrial Laser Scans at the Feature and Decision Levels. Sensors 2013, 13, 1614-1634. [CrossRef] [PubMed]

37. Maas, H.; Bienert, A.; Scheller, S.; Keane, E. Automatic forest inventory parameter determination from terrestrial laser scanner data. Int. J. Sens. 2008, 29, 1579-1593. [CrossRef]

38. Koreň, M.; Mokroš, M.; Bucha, T. Accuracy of tree diameter estimation from terrestrial laser scanning by circle-fitting methods. Int. J. Appl. Earth Obs. Geoinformation 2017, 63, 122-128. [CrossRef]

39. Pitkänen, T.P.; Raumonen, P.; Kangas, A. Measuring stem diameters with TLS in boreal forests by complementary fitting procedure. ISPRS J. Photogramm. Sens. 2019, 147, 294-306. [CrossRef]

40. Saarinen, N.; Kankare, V.; Vastaranta, M.; Luoma, V.; Pyörälä, J.; Tanhuanpää, T.; Liang, X.; Kaartinen, H.; Kukko, A.; Jaakkola, A.; et al. Feasibility of Terrestrial laser scanning for collecting stem volume information from single trees. ISPRS J. Photogramm. Sens. 2017, 123, 140-158. [CrossRef] 
41. Ducey, M.J.; Granhus, A.; Ritter, T.; Von Lüpke, N.; Astrup, R. Approaches for estimating stand-level volume using terrestrial laser scanning in a single-scan mode. Can. J. 2014, 44, 666-676.

42. Moskal, L.M.; Zheng, G. Retrieving forest inventory variables with terrestrial laser scanning (TLS) in urban heterogeneous forest. Remote Sens. 2012, 4, 1-20. [CrossRef]

43. Pueschel, P.; Newnham, G.; Rock, G.; Udelhoven, T.; Werner, W.; Hill, J. The influence of scan mode and circle fitting on tree stem detection, stem diameter and volume extraction from terrestrial laser scans. ISPRS J. Photogramm. Sens. 2013, 77, 44-56. [CrossRef]

44. Kankare, V.; Liang, X.; Yu, X.; Hyyppa, J.; Holopainen, M. Automated Stem Curve Measurement Using Terrestrial Laser Scanning. IEEE Trans. Geosci. Sens. 2014, 52, 1739-1748.

45. Calders, K.; Newnham, G.; Burt, A.; Murphy, S.; Raumonen, P.; Herold, M.; Culvenor, D.; Avitabile, V.; Disney, M.; Armston, J. Nondestructive estimates of above-ground biomass using terrestrial laser scanning. Methods Ecol. Evol. 2015, 6, 198-208. [CrossRef]

46. Yu, X.; Liang, X.; Hyyppä, J.; Kankare, V.; Vastaranta, M.; Holopainen, M. Stem biomass estimation based on stem reconstruction from terrestrial laser scanning point clouds. Sens. Lett. 2013, 4, 344-353. [CrossRef]

47. Kankare, V.; Holopainen, M.; Vastaranta, M.; Puttonen, E.; Yu, X.; Hyyppä, J.; Vaaja, M.; Hyyppä, H.; Alho, P. Individual tree biomass estimation using terrestrial laser scanning. ISPRS J. Photogramm. Sens. 2013, 75, 64-75. [CrossRef]

48. Holopainen, M.; Vastaranta, M.; Kankare, V.; Räty, M.; Vaaja, M.; Liang, X.; Yu, X.; Hyyppä, J.; Hyyppä, H.; Viitala, R. Biomass estimation of individual trees using stem and crown diameter TLS measurements. ISPRS Int. Arch. Photogramm. Remote Sens. Spat. Inf. Sci. 2011, 3812, 91-95. [CrossRef]

49. Pfeifer, N.; Winterhalder, D. Modelling of tree cross sections from terrestrial laser scanning data with free-form curves. Int. Arch. of Photogramm. Remote Sens. Spat. Inf. Sci. 2004, 36, W2.

50. Liang, X.; Hyyppä, J.; Kaartinen, H.; Lehtomäki, M.; Pyörälä, J.; Pfeifer, N.; Holopainen, M.; Brolly, G.; Francesco, P.; Hackenberg, J.; et al. International benchmarking of terrestrial laser scanning approaches for forest inventories. ISPRS J. Photogramm. Sens. 2018, 144, 137-179. [CrossRef]

51. Sheppard, J.; Morhart, C.; Hackenberg, J.; Spiecker, H. Terrestrial laser scanning as a tool for assessing tree growth. iForest-Biogeosci. For. 2016, 10, 172. [CrossRef]

52. Kaasalainen, S.; Krooks, A.; Liski, J.; Raumonen, P.; Kaartinen, H.; Kaasalainen, M.; Puttonen, E.; Anttila, K.; Mäkipää, R. Change Detection of Tree Biomass with Terrestrial Laser Scanning and Quantitative Structure Modelling. Remote. Sens. 2014, 6, 3906-3922. [CrossRef]

53. Mengesha, T.; Hawkins, M.; Nieuwenhuis, M. Validation of terrestrial laser scanning data using conventional forest inventory methods. Eur. J. For. Res. 2015, 134, 211-222. [CrossRef]

54. Srinivasan, S.; Popescu, S.C.; Eriksson, M.; Sheridan, R.D.; Ku, N.-W. Multi-temporal terrestrial laser scanning for modeling tree biomass change. Ecol. Manag. 2014, 318, 304-317. [CrossRef]

55. Liang, X.; Hyyppa, J.; Kaartinen, H.; Holopainen, M.; Melkas, T. Detecting Changes in Forest Structure over Time with Bi-Temporal Terrestrial Laser Scanning Data. ISPRS Int. J. Geo-Inf. 2012, 1, 242-255. [CrossRef]

56. Newnham, G.J.; Armston, J.D.; Calders, K.; Disney, M.I.; Lovell, J.L.; Schaaf, C.B.; Strahler, A.H.; Danson, F.M. Terrestrial Laser Scanning for Plot-Scale Forest Measurement. For. Rep. 2015, 1, 239-251. [CrossRef]

57. Vastaranta, M.; Melkas, T.; Holopainen, M.; Kaartinen, H.; Hyyppä, J.; Hyyppä, H.J.P.J.F. Laser-based Field Measurements in Tree-Level Forest Data Acquisition. Photogramm. J. Finl 2009, 21, 51-61.

58. Young-Pow, C.; Treitz, P.; Hopkinson, C.; Chasmer, L. Assessing forest metrics with a ground-based scanning lidar. Can. J. 2004, 34, 573-583.

59. Luoma, V.; Saarinen, N.; Wulder, M.A.; White, J.C.; Vastaranta, M.; Holopainen, M.; Hyyppä, J. Assessing Precision in Conventional Field Measurements of Individual Tree Attributes. Forests 2017, 8, 38. [CrossRef]

60. Schiffel, A. Form und Inhalt der Fichte (Form and volume of spruce). Mitt. aus d. forstl. Versuchsan. Osterreiche 1899, 24.

61. Muller-Landau, H.C.; Condit, R.S.; Harms, K.E.; Marks, C.O.; Thomas, S.C.; Bunyavejchewin, S.; Chuyong, G.; Co, L.; Davies, S.; Foster, R.; et al. Comparing tropical forest tree size distributions with the predictions of metabolic ecology and equilibrium models. Ecol. Lett. 2006, 9, 589-602. [CrossRef]

62. Dobbertin, M.; Neumann, M.; Schroeck, H.-W. Tree Growth Measurements in Long-Term Forest Monitoring in Europe. In Developments in Environmental Science; Elsevier BV: Amsterdam, The Netherlands, 2013; Volume 12, pp. 183-204. 
63. Tansey, K.; Selmes, N.; Anstee, A.; Tate, N.J.; Denniss, A. Estimating tree and stand variables in a Corsican Pine woodland from terrestrial laser scanner data. Int. J. Sens. 2009, 30, 5195-5209. [CrossRef]

64. Seidel, D.; Hoffmann, N.; Ehbrecht, M.; Juchheim, J.; Ammer, C. How neighborhood affects tree diameter increment-New insights from terrestrial laser scanning and some methodical considerations. Ecol. Manag. 2015, 336, 119-128. [CrossRef]

65. Wang, Y.; Lehtomäki, M.; Liang, X.; Pyörälä, J.; Kukko, A.; Jaakkola, A.; Liu, J.; Feng, Z.; Chen, R.; Hyyppä, J. Is field-measured tree height as reliable as believed-A comparison study of tree height estimates from field measurement, airborne laser scanning and terrestrial laser scanning in a boreal forest. ISPRS J. Photogramm. Sens. 2019, 147, 132-145. [CrossRef]

(C) 2019 by the authors. Licensee MDPI, Basel, Switzerland. This article is an open access article distributed under the terms and conditions of the Creative Commons Attribution (CC BY) license (http://creativecommons.org/licenses/by/4.0/). 